\title{
In and out of the loop: external and internal modulation of the olivo-cerebellar loop
}

\author{
Avraham M. Libster ${ }^{1,2 *}$ and Yosef Yarom ${ }^{1,2}$ \\ ' Department of Neurobiology, Life Science Institute, Hebrew University, Jerusalem, Israel \\ 2 Edmund and Lily Safra Center for Brain Sciences, Hebrew University, Jerusalem, Israel
}

\author{
Edited by: \\ Egidio D'Angelo, University of \\ Pavia, Italy \\ Reviewed by: \\ Gilad Silberberg, Karolinska \\ Institute, Sweden \\ Deborah Baro, Georgia \\ State University, USA \\ *Correspondence: \\ Avraham M. Libster, Department \\ of Neurobiology, Life Science \\ Institute, Hebrew University, \\ Silberman Building, Jerusalem \\ 91904, Israel. \\ e-mail: avi.libster@mail.huji.ac.il
}

\begin{abstract}
Cerebellar anatomy is known for its crystal like structure, where neurons and connections are precisely and repeatedly organized with minor variations across the Cerebellar Cortex. The olivo-cerebellar loop, denoting the connections between the Cerebellar cortex, Inferior Olive and Cerebellar Nuclei (CN), is also modularly organized to form what is known as the cerebellar module. In contrast to the relatively organized and static anatomy, the cerebellum is innervated by a wide variety of neuromodulator carrying axons that are heterogeneously distributed along the olivo-cerebellar loop, providing heterogeneity to the static structure. In this manuscript we review modulatory processes in the olivo-cerebellar loop. We start by discussing the relationship between neuromodulators and the animal behavioral states. This is followed with an overview of the cerebellar neuromodulatory signals and a short discussion of why and when the cerebellar activity should be modulated. We then devote a section for three types of neurons where we briefly review its properties and propose possible neuromodulation scenarios.
\end{abstract}

Keywords: cerebellum, neuromodulation, olivo-cerebellar loop, aminergic modulation, inferior olive, cerebellar nuclei, cerebellar cortex

\section{INTRODUCTION}

The close relationships between the psychiatric state and the motor system is beautifully demonstrated in a clinical report describing a post-traumatic disorder case where exposure to loud sound lead to tremors lasting from several minutes to several days (Walters and Hening, 1992). The observed reaction to loud sound is a classic symptom of Psychogenic Tremor (PT), a movement disorder classified as Psychogenic Motor Disorder (PMD) (Jankovic et al., 2006). PMD, as its name suggests, is a movement disorder having a psychological origin (Association, 2000) and it clearly demonstrate that the properties of the motor control system can be altered on a transition to a different behavioral state.

The shifts between different behavioral states are commonly observed in animal behavior (Irwin, 1968). The shifts, which can be triggered by either internal or external stimuli, can be accompanied by changes in motor activity. Switching between the different states allows the animal to cope with changes that happened or about to happen in the external world. It is of no surprise that each behavioral state is accompanied by a distinct global brain activity manifested over different brain areas. A variety of physiological measurements, EEG (Lindsley, 1952), LFP

\footnotetext{
Abbreviations: bPN, Big Projection Neuron; CF, Climbing Fibers; CN, Cerebellar Nuclei; DAO, Dorsal Accessory Olivary Nucleus; DN, Dentate Nucleous; DRN, Dorsal Reticular Nucleus; GiC, Nucleus Reticularis Gigantocellularis/Paragigantocellularis Complex; IN, Interposed Cerebellar Nucleus; IO, Inferior Olive; LC, Locus Coeruleus; MAO, Medial Accessory Olivary Nucleus; MdR, Medullary Reticular Formation; MF, Mossy Fibers; PC, Purkinje Cell; PeFLH, Perifornical Part of Lateral Hypothalamus; PnO, Oral Pontine Reticularis nucleus; PnR, Pontine Reticular Formation; PTn, Pedunculopontine Tegmental Nucleus; ROb, Raphe Obscurus Nucleus; RPa, Raphe Pallidus Nucleus; TMN, Tuberomammillary Nucleus; VTA, Ventral Tegmental Area.
}

(Gervasoni et al., 2004), and single unit activity (Abeles et al., 1995; Fanselow et al., 2001; Steriade et al., 2001), were used to characterize a state related brain activity [reviewed in Lee and Dan (2012)].

Changing global brain activity doesn't seem to be a cascading event but rather a simultaneous modification in activity of many parts of the CNS. The coordinated modification is regulated by a set of subcortical structures, each composed of neurons containing aminergic substances (Graeff et al., 1996; Everitt and Robbins, 1997; Taheri et al., 2002; Berridge and Waterhouse, 2003; Burgess, 2010). These aminergic substances, operates as neuromodulators, binding to specific, usually metabotropic membrane receptors. Upon binding they affect both, the cells intrinsic properties and the properties of the synaptic inputs. Neuromodulators can be co-released with neurotransmitters, such as glutamate (Trudeau, 2004), either at or in the vicinity of the synaptic site. Alternatively neuromodulators can have a global effect via what is known as volume transmission. A neuromodulator is said to be volume transmitted when it release sites and the matching receptors, in the target area, are relatively far from each other (Agnati et al., 2006).

Measuring the activity of neurons in these subcortical areas shows correlation between their activity and the animal behavioral state, i.e., both serotonergic neurons in the Dorsal Reticular Nucleus (DRN) and noradrenergic neurons in the Locus Coeruleus (LC) increase their rate of activation as the animal shifts from REM sleep through quite wakefulness to attentive behavior (Hobson et al., 1975; Trulson and Jacobs, 1979; Veasey et al., 1997; Jacobs et al., 2002). The role of aminergic neurons has been recently supported by experiments using optogenetic tools, showing that specific alteration of the activity in these 
areas affected the animal sleep-awake cycle and motor behavior (Carter et al., 2010; McGregor and Siegel, 2010), social behavior (Chaudhury et al., 2013) and attention (Narayanan et al., 2012).

Within a behavioral state the neuromodulatory system operates in two release modes: tonic and phasic. While tonic release, which lasts throughout the behavioral state, regulates nonspecific aspects, the phasic release is activated by specific stimuli or during specific task. For example dopaminergic neurons encode the predicted reward of stimuli (Schultz et al., 1997; Hollerman and Schultz, 1998), neurons in the LC have different responses to target or distractor stimuli in visual discrimination tasks (Aston-Jones et al., 1999) and serotonergic neurons in the DRN exhibit stimulus related (Ranade and Mainen, 2009) and specific motor activity (Veasey et al., 1995; Jacobs and Fornal, 1997) related firing.

\section{EXTRINSIC AND INTRINSIC MODULATION}

Neuromodulation in the CNS can be divided to extrinsic and intrinsic systems. The subcortical structures described in the previous section are extrinsic, as they are located outside the modulated target structure and operate almost independently of the target structure's activity. In intrinsic system the source of the modulating substance is within the structure and its release is almost entirely dependent on the activity of the local neural circuit. Another distinction between the systems is the possibility of activation of only subset of the secretory cells thus providing the intrinsic neuromodulatory system with a better spatial resolution.

In the case of the cerebellum, some of the extrinsic neuromodulators are: 5-HT, Dopamine, Ach, NE, Orexin and Histamine. The release pattern of these neuromodulators is relatively independent of the activity of the olivo-cerebellar loop [i.e., dopamine, (Rogers et al., 2011)]. Intrinsic neuromodulators, such as CRF [reviewed by Ito (2009)], Endocannabinoids (Safo et al., 2006), NO (Shibuki and Okada, 1991; Saxon and Beitz, 1996) and glutamate (Kano et al., 2008), are mostly produced and released within, and under the control of the olivo-cerebellar loop.

\section{THE CEREBELLUM IN DIFFERENT BEHAVIORAL STATES}

The neuromodulators of the cerebellum are well documented. Numerous subcortical areas such as the hypothalamus (Dietrichs and Haines, 1989), Ventral Tegmental Area (VTA) (Ikai et al., 1992, 1994), DRN (Pierce et al., 1977; Mendlin et al., 1996) and LC (Somana and Walberg, 1979) provide various modulatory agents (Figure 1) and their effects on different parts of the olivo-cerebellar loop, both in vivo and in vitro were documented (Schweighofer et al., 2004). Yet, the role of the cerebellum in different behavioral states was largely ignored.

One of the few studies on cerebellar function and its relation to behavioral state, recently published by Wu et al., demonstrated that the timing activity in the cerebellum is awareness independent. It concludes that coding of the sensory stimuli timing is largely independent of "... attentional, top-down or cognitive control mechanisms” (Wu et al., 2011). Although it might imply that cerebellar function is independent of the behavioral state, we argue that in order to preserve the cerebellar "timing function," and given that the cerebellar circuitry is modified upon the shift in the behavioral state, one have to change the "coding of time." In generalizing this idea, we argue that given a global change of brain activity, the input to the cerebellum and the response to cerebellar output are bound to change. Therefore, cerebellar activity most be modified in order to either ensure that the response is independent of the behavioral state or to provide a response that fit the behavioral requirements of the new state (Figure 2).

In the following sections we will review the effects of neuromodulators on one cell type from each of the constituents of the olivo-cerebellar loop: the Cerebellar Nuclei (CN) neuron, the Purkinje Cell (PC) and olivary neurons. For each cell type, we will describe one of its many observed electrophysiological phenomena and speculate on possible modulation scenarios.

\section{THE CN NEURONS}

\section{THE BIOPHYSICAL PROPERTIES OF CN NEURONS}

One of the ongoing debates in the field of cerebellar research is whether the output of the cerebellar cortex is conveyed via the rebound burst occurring in the CN neurons (Alviña et al., 2008; Boehme et al., 2011). Rebound burst (see Figure 3A) is a high frequency spikes burst triggered by a prolonged period of hyperpolarization (Tadayonnejad et al., 2010). The rebound response in $\mathrm{CN}$ neurons is mediated by the activation of T-type calcium channels (Cav3.x) and HCN channels (Molineux et al., 2006, 2008; Alviña et al., 2009; Engbers et al., 2011). The expression of either Cav3.1, or Cav 3.3, governs the number of spikes in the rebound burst and their inter-spike-intervals (see Figure 3B). The activation of these channels, expressed in the soma and non-uniformly distributed along the dendrites (Gauck et al., 2001; McKay et al., 2006), trigger either "strong" or "weak" bursts reported in vitro (Molineux et al., 2006). The HCN channels generate a non-specific, slowly inactivated cationic current (h-current). This current, which is activated by membrane hyperpolarization (Wahl-Schott and Biel, 2009), contributes to the rebound response by increasing the depolarization at the end of a hyperpolarizing period. The depolarization will act to increase the intra-burst firing rate and decrease the variance of the latency to the first spike (Engbers et al., 2011) (Figure 3C). The three types of $\mathrm{HCN}$ channels found in the $\mathrm{CN}$ neurons are HCN1, HCN2 and $\mathrm{HCN}$ 4. The HCN variants are spatially segregated: $\mathrm{HCN} 2$ is located proximally whereas HCN4 is found mainly at the distal dendrites (Santoro et al., 2000; Notomi and Shigemoto, 2004). Out of the three $\mathrm{HCN}$ isoforms, $\mathrm{HCN} 2$, and $\mathrm{HCN} 4$ are more susceptible to regulation by cAMP levels. An increase in intracellular cAMP concentration causes a rightward shift of the HCN activation curve and induces faster opening kinetics (Wahl-Schott and Biel, 2009).

\section{NEUROMODULATION OF CN NEURONS}

Table 1 summarizes some of the current knowledge on the neuromodulators operating within the $\mathrm{CN}$. Here we describe presumable modulation strategies that can change the output of the $\mathrm{CN}$ by altering either the "rebound response" or modulating the $\mathrm{CN}$ inputs.

The most straightforward modulation of rebound response is to change the kinetic of either the calcium current, the h-current or both. Modulation of the t-type or HCN channel kinetics can either change the frequency of spikes in the burst or the latency 


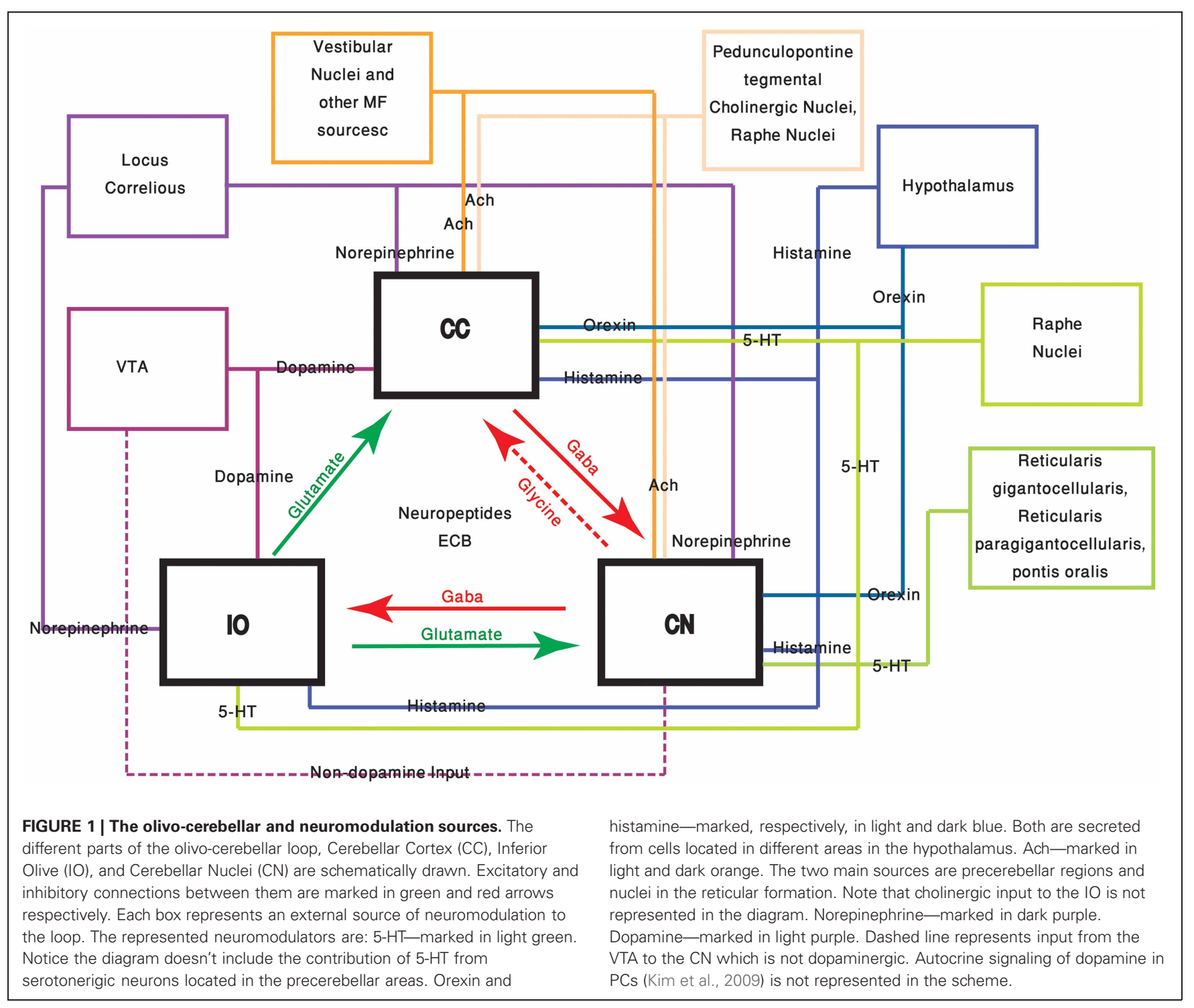

to the first spike (Figure 3A inset) (Engbers et al., 2011). While changing the time of the first spike is bound to change the "time representation," changing the frequency of the burst will alter the intensity of the $\mathrm{CN}$ output. The later may reflect the need to adapt to the new behavioral state.

HCN channels, as mentioned above, are regulated by the intracellular levels of cAMP and cGMP. Since many neuromodulatory pathways use cAMP and cGMP as second messengers, the modulation of HCN channels during a shift in behavioral state is likely to occur. Therefore, we will consider possible interesting scenarios of HCN modulation.

One of the intriguing neuromodulation scenarios is the differential effect on specific input. Neurons assign "value" to the different inputs carried by afferents from diverse pathways. This "value" is determined by either the location of the input or its relative strength. Differential neuromodulation can occur if the neuromodulators receptors are non-homogeneously distributed [This scenario, among many others, is discussed in (Dayan, 2012)].
The big Projection Neurons (bPNs) of the CN are suited for differential neuromodulation. A typical bPN receives excitatory input from the Mossy Fibers (MF) and Climbing Fibers (CF) collaterals and inhibitory input from PCs and local interneurons. Studies have shown that, at least in the Dentate Nucleus (DN), PCs synapses are located at the soma with a decreasing gradient along the dendrites. The MF excitatory input, on the other hand, is mostly located on the distal parts of the dendritic tree, as oppose to the CF input that is found on proximal dendrites (Chan-Palay, 1977; Uusisaari and Knöpfel, 2011). Furthermore, a non-homogeneous distribution of HCN channel has been reported (Santoro et al., 2000; Notomi and Shigemoto, 2004; Wilson and Garthwaite, 2010) as well as location specific innervations of neuromodulators [i.e., the cholinergic system has synaptic junctions close to the dendrites (Jaarsma et al., 1997)]. As a result of this high degree of non-uniformity, neuromodulation can be highly specific. For example, modulation of HCN channels located at the distal part of the dendrites will affect the input from the MF while modulation of the more proximal parts 


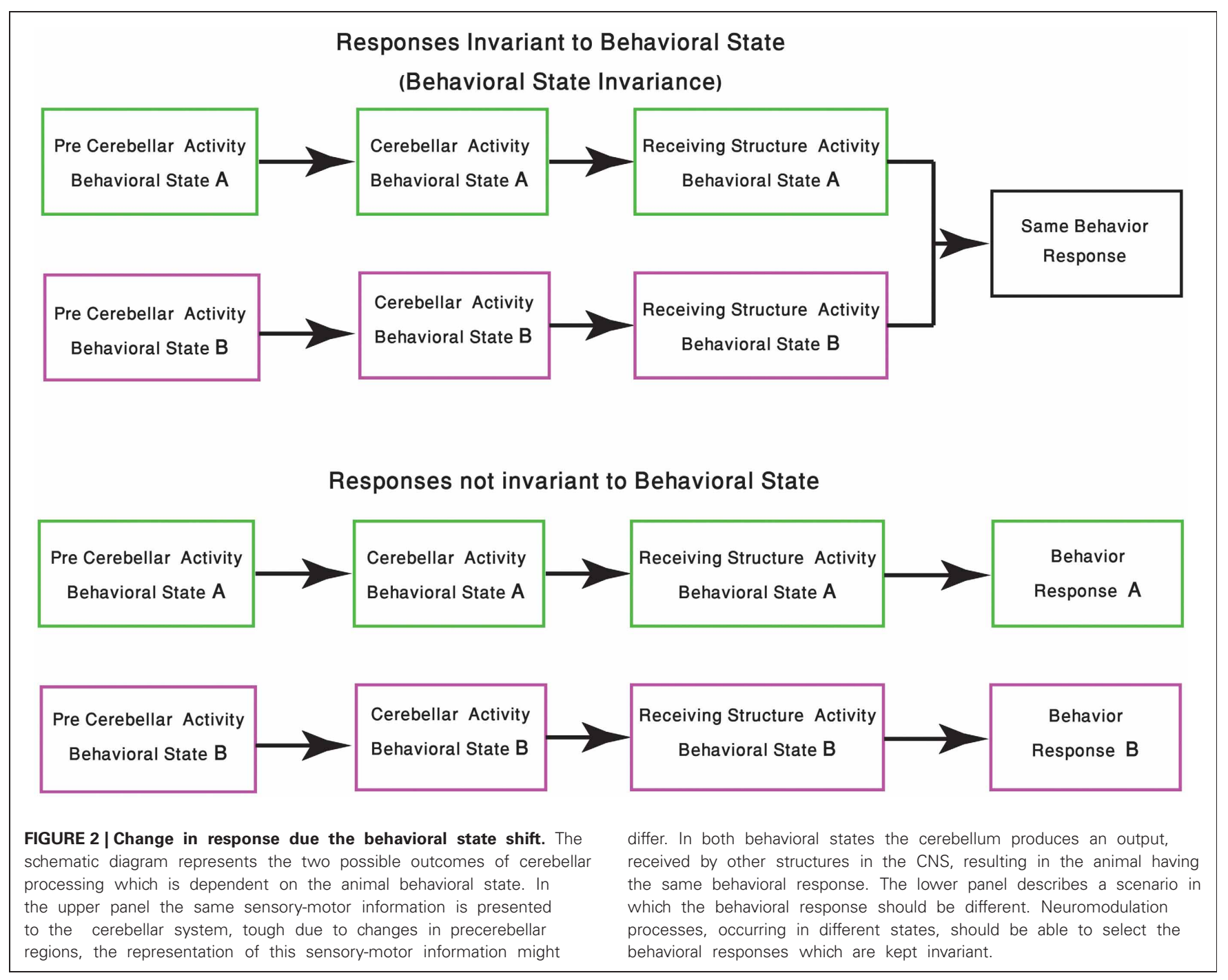

of the dendrite can affect the CF input. This modulation strategy enables the bPN to selectively augment or attenuate EPSPs of different input sources. This "input" targeted modulation, can be viewed as a way of differentially changing the "sensitivity" of a bPN to inputs from the olivo-cerebellar loop or external input from precerebellar regions. Interestingly, this effect might also be achieved by modulating T-type calcium channels. The Ttype channels are expressed in distal parts of the dendrite (Gauck et al., 2001) and might play a role in amplifying the excitatory input as seen in other parts of the CNS (i.e., Urban et al., 1998).

What are the advantages of having a differential modulation of rebound burst and excitatory input? We may answer it by assuming a different "expected" bPN output during different input regimes. When most of the inputs are inhibitory, prolonged hyperpolarization of the bPN membrane potential will enable the rebound burst mechanism. The rebound burst can then be considered as the "expected" output. In this case modulation of the rebound burst properties would have it largest effect on the information, conveyed by the bPN to the rest of CNS. On the other hand when the bPN receives prolonged excitatory drive, inhibition will modulate the timing and intensity of bPN response (Holdefer et al., 2005). In the "excitatory" input regime, modulation of EPSPs and spiking probability will have a larger effect on the information, conveyed by the bPN to the rest of CNS, then changing the properties of the rebound burst.

\section{THE PURKINJE CELLS}

\section{THE BIOPHYSICAL PROPERTIES OF PURKINE CELLS}

The properties of cerebellar PC have been extensively studied both in vitro and in vivo in anaesthetized and awake animals. It is commonly accepted that these unique neurons are endowed with a variety of ionic channels that provide a large repertoire of electrical activity (Llinas and Sugimori, 1980a,b; Williams et al., 2002). It is beyond the scope of this manuscript to review the vast literature describing the electrophysiological properties of PC and therefore we will limit our description to few of these properties. The three main ionic currents that control the firing of PC are $\mathrm{Na}, \mathrm{Ca}$ and h-current. To this short list one should add a variety of potassium currents that are either voltage dependent, 


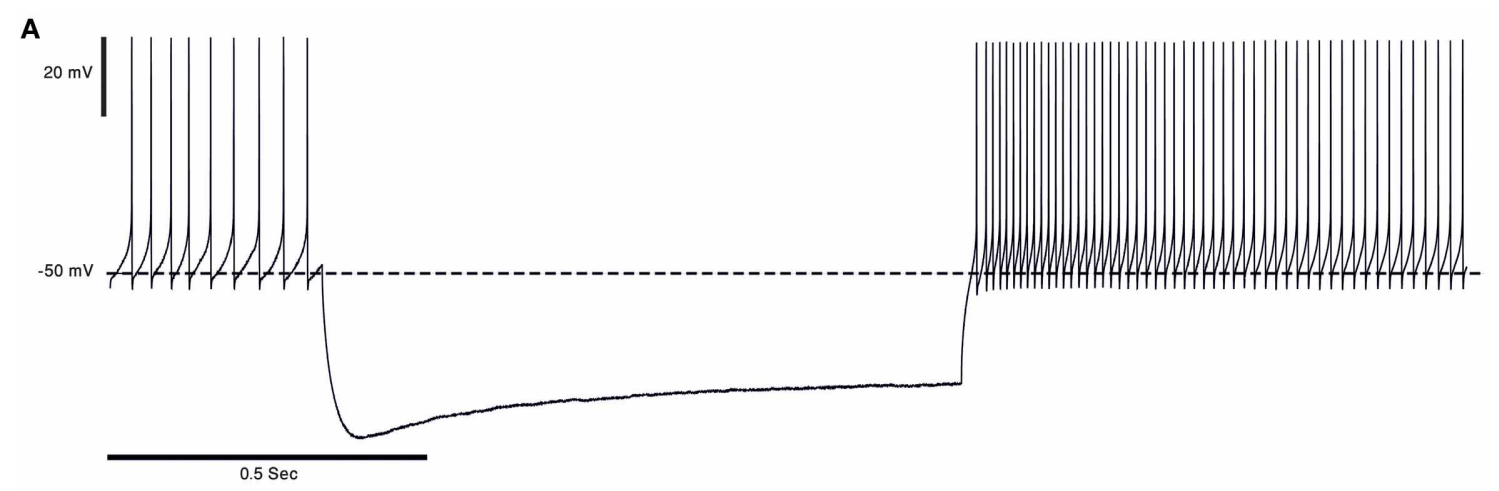

B

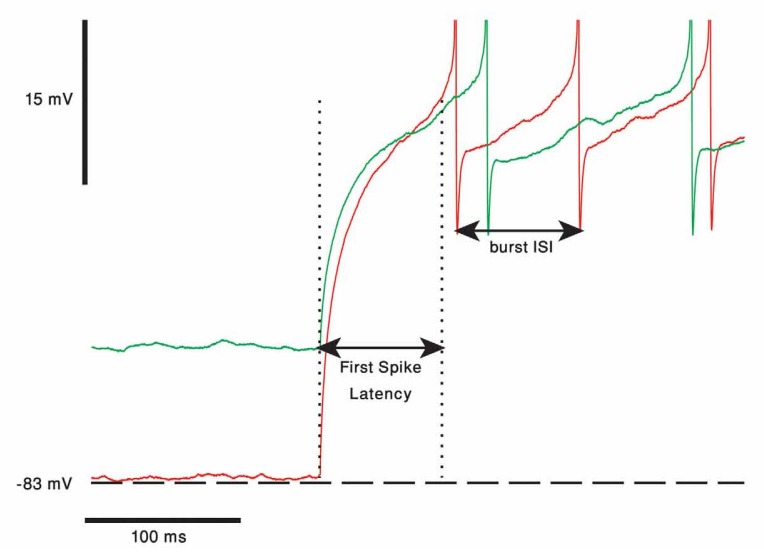

C

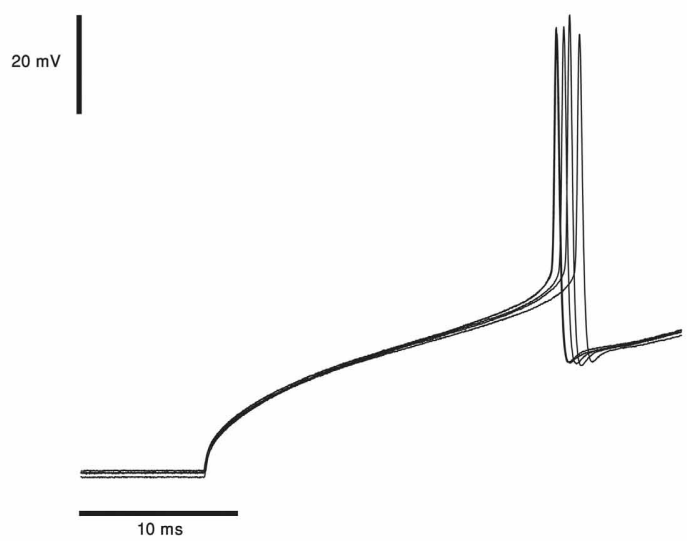

FIGURE 3 | Rebound burst in CN neurons. (A) Voltage trace from in vitro recording of a bPN. In response to $1 \mathrm{~s}$ of hyperpolarization the cell responds with a long rebound burst response, as evident in the increase in firing rate. Notice the voltage "sag" clearly visible during the hyperpolarization of the membrane voltage, probably due to activation of HCN channels (the voltage traces are courtesy of Dr. Uusisaari). (B) Rebound burst in response to different hyperpolarization levels. The first spike latency was shorter and burst frequency was higher when the membrane voltage was more hyperpolarized (red). Spikes were cut for better visualization. (C) The first spikes in the rebound burst from five repeats of the protocol, from panel (A), done on the same cell. The latency to the first spike has a clear and noticeable small jitter. calcium dependent or both. While the first three currents control the excitability of the neurons, the potassium currents have a prominent role in shaping the frequency and pattern of activity (Womack and Khodakhah, 2002, 2004). The kinetics of most, if not all, of these ionic currents can be modified by neuromodulators, resulting in a profound change in the electrical behavior.

One of the most characteristic features of PCs is their high firing rate, which can go up to $200 \mathrm{~Hz}$ and last for prolonged periods of time (Loewenstein et al., 2005; Shin et al., 2007). It has been proposed that this high firing frequency reflects intrinsic properties rather than the rate of synaptic inputs. Indeed, PC firing, in vivo and in vitro, persists in the presence of various synaptic blockers. It follows that the intrinsic properties determine the level of firing, upon which the synaptic inputs provides fine modulation. More recently, it was demonstrated that under in vitro conditions, as well as under anesthesia, the firing pattern is characterized by abrupt transitions between tonic firing and quiescence (Figure 4A). The terms "up" and "down" states were assigned to denote the firing and the quiescent periods and a corresponding bistable membrane potential has been demonstrated [for a review see (Engbers et al., 2012)]. Whether these transitions occur in awake behaving animals is still debated [see (Yartsev et al., 2009) but (Schonewille et al., 2006)]. Regardless of its outcome, this debate shows the importance of the underlying fact that the firing properties of PCs are robustly modulated between different behavioral states.

\section{NEUROMODULATION OF PURKINJE CELLS}

Table 2 summarizes some of the current knowledge on the neuromodulators operating in the cerebellar cortex particularly on PCs. We then use this case to discuss and compare the possibilities of phasic and tonic effects of neuromodulation.

Receptors for the same modulator having different affinity might play a key role in the ability of cerebellar system to respond to tonic and phasic neuromodulatory signals, providing the system with the ability to modulate its processing over different time scales while preserving its ability to response to transient signals. In the tonic release state, where a low level of the modulator is present, the high affinity receptor will be activated (Figure 4C). Thus, it is likely that this receptor will monitor the different basal level of the neuromodulator, 
Table 1 | Neuromodulators of $\mathrm{CN}$.

\begin{tabular}{|c|c|c|c|}
\hline Neuromodulator & Source & Receptors & Known effects \\
\hline 5-HT & $\begin{array}{l}\text { GiC, PnO (Bishop and Ho, } \\
\text { 1985). }\end{array}$ & $\begin{array}{l}\text { 5-HT1B (might be expressed by } \\
\text { PCs axons) 5-HT1C,5-HT2A, 5-HT2B } \\
\text { (Might be expressed only in IN) } \\
\text { 5-HT3 (low levels), 5-HT5A (Choi } \\
\text { and Maroteaux, 1996; Kia et al., } \\
\text { 1996; Sari et al., 1999; Geurts et al., } \\
\text { 2002). }\end{array}$ & $\begin{array}{l}\text { In vitro } \\
\text { Attenuates the HCN current and decreases the amplitude of } \\
\text { IPSCs by a presynaptic mechanism (Saitow et al., 2009). } \\
\text { Increases the firing rate and reduces the response to } \\
\text { glutamate via a postsynaptic mechanism (Gardette et al., } \\
\text { 1987). } \\
\text { In vivo } \\
\text { 5-HT1A and 5-HT2 agonists induce a decrease in firing rate } \\
\text { and 5-HT5A agonist increase firing rate (Di Mauro et al., } \\
\text { 2003). In other studies only decreases in firing rate and } \\
\text { response to glutamate, were documented (Kitzman and } \\
\text { Bishop, 1997). Neurons excited by 5-HT were located at } \\
\text { cerebellar nuclei projecting to the thalamus and cortex, } \\
\text { whereas the nuclei projecting to peripheral motor centers } \\
\text { reduced their firing rate when levels of 5-HT increased (Di } \\
\text { Mauro et al., 2003). }\end{array}$ \\
\hline $\mathrm{NE}$ & $\begin{array}{l}\text { LC (Hokfelt and Fuxe, } \\
\text { 1969; Somana and } \\
\text { Walberg, 1978). }\end{array}$ & & $\begin{array}{l}\text { In vivo } \\
\text { Direct application of NE decreases the firing rate of neurons } \\
\text { in all nuclei (Di Mauro et al., 2003). } \\
\text { Decreases response to application of GABA in the FN and } \\
\text { Posterior IN while increasing it in the anterior IN. The LN has } \\
\text { mixed responses (Di Mauro et al., 2012). }\end{array}$ \\
\hline
\end{tabular}

\begin{tabular}{|c|c|c|c|}
\hline Ach & $\begin{array}{l}\text { Vestibular nuclei } \\
\text { (non-beaded fibers) PTg, } \\
\text { GiC and Raphe nuclei } \\
\text { (beaded fibers creating a } \\
\text { dense network) (Jaarsma } \\
\text { et al., 1997). }\end{array}$ & & \\
\hline Dopamine & $\begin{array}{l}\text { But source of dopamine is } \\
\text { unknown as nuclei is } \\
\text { innervated by } \\
\text { non-dopaminergic } \\
\text { neurons from the VTA } \\
\text { (lkai et al., 1992). }\end{array}$ & $\begin{array}{l}\text { DAT presence is demonstrated } \\
\text { (Delis et al., 2004, 2008). }\end{array}$ & \\
\hline Histamine & $\begin{array}{l}\text { TMN (Haas and Panula, } \\
\text { 2003). }\end{array}$ & $\begin{array}{l}\mathrm{H} 1, \mathrm{H} 2 \text { (Qin et al., 2011) and H3 } \\
\text { (mRNA in FN and IN) (Pillot et al., } \\
\text { 2002). }\end{array}$ & $\begin{array}{l}\text { In vitro } \\
\text { Increases firing rate of neurons in all of the CN, probably } \\
\text { through } \mathrm{H} 2 \text { activation (Shen et al., 2002; Tang et al., 2008; } \\
\text { Qin et al., 2011). }\end{array}$ \\
\hline Orexin & $\begin{array}{l}\text { PeFLH (Peyron et al., } \\
\text { 1998). }\end{array}$ & $\begin{array}{l}\text { OX1R, OX2R (Hervieu et al., 2001; } \\
\text { Cluderay et al., 2002). }\end{array}$ & $\begin{array}{l}\text { In vitro } \\
\text { Increases firing rate of neurons in the IN probably through } \\
\text { OX2R activation (Yu et al., 2010). }\end{array}$ \\
\hline
\end{tabular}

providing long time scale modulation. When a sudden increase in neuromodulator occurs, the second receptor will be activated, enabling the system to respond to transient signals. As mentioned above, tonic and phasic release is a common strategy in neuromodulatory systems [reviewed in depth in Dayan (2012)].

The CRF system in the cerebellum is an example of a tonic and phasic modulation system. CRF, a neuropeptide, is released from both the MFs and the CFs (Cummings et al., 1989; Errico and Barmack, 1993). In the cerebellar cortex, the two CRF receptors
CRF-R1 and CRF-R2 are expressed in all of the PCs. The two receptor types have a compartment specific distribution pattern (illustrated in Figure 4B) (King and Bishop, 2002; Lee et al., 2004). The properties of the olivo-cerebellar CRF system that support phasic and tonic modulation by the same modulator are: (1) Two receptor types with different affinity to CRF (Lovenberg et al., 1995) (2) A tonic and phasic components [although this hasn't been thoroughly examined, there are some supporting evidence; (Barmack and Young, 1990; Tian and Bishop, 2003; Beitz and Saxon, 2004)] (3) Two distinct sources of CRF, the CF, and 


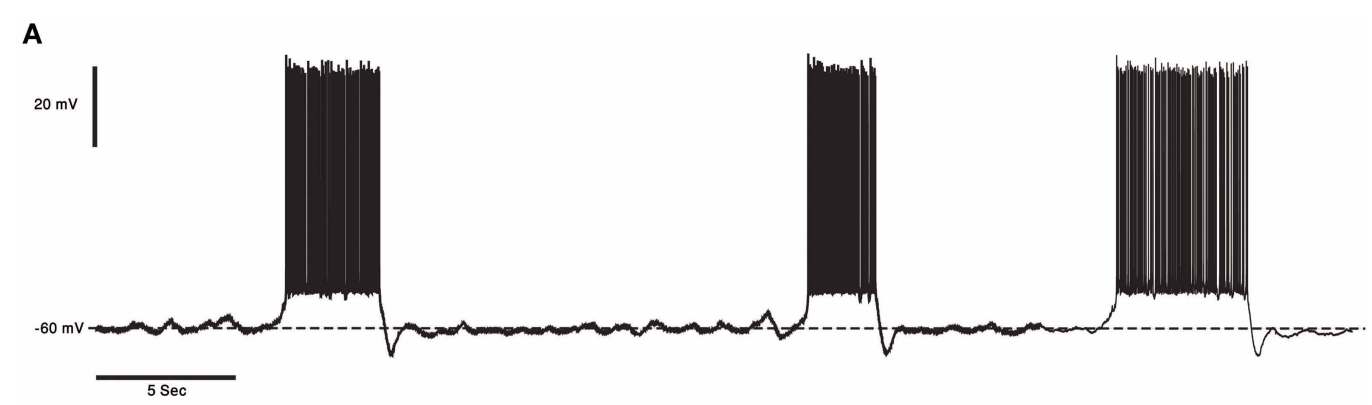

B

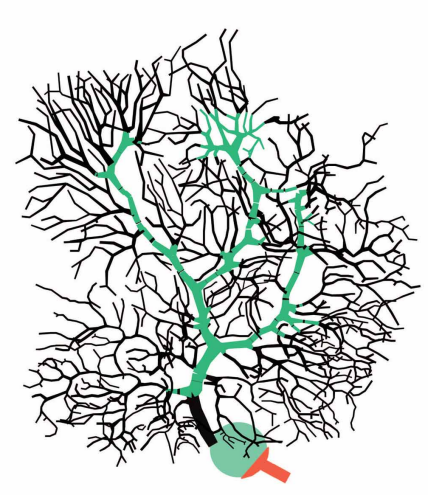

C

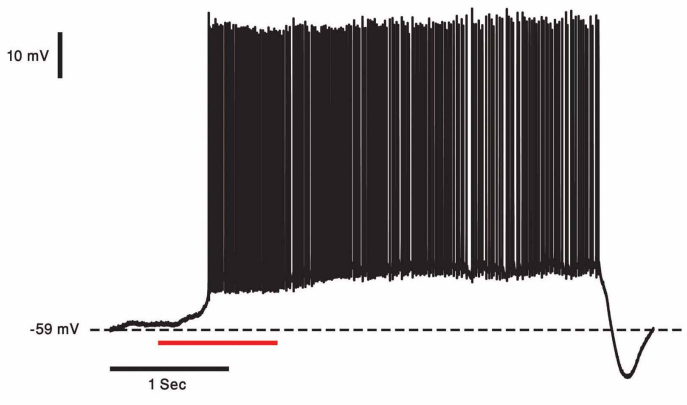

$\mathbf{E}$

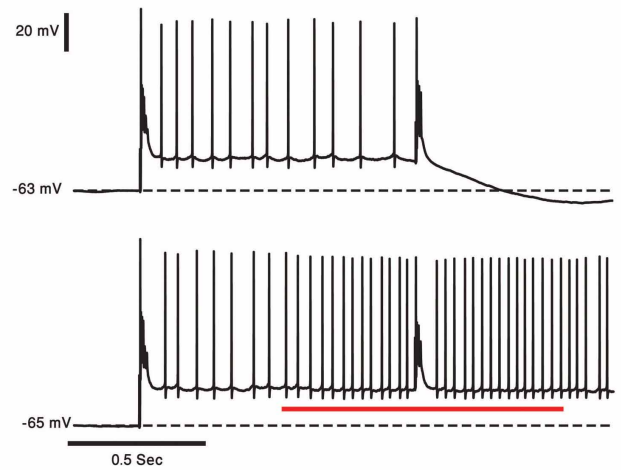

FIGURE 4 | PCs and two Receptors modulation. (A) Voltage trace from in vitro recording of a PC. The PC two states of membrane voltage, the "up" and "down" state are visible. (B) Schematic representation of the two receptor model. In this case the receptor with high affinity (green) is localized to soma and proximal dendrite and the Low affinity receptor (orange) is localized to the axon hillock and initial segment. This compartmental distribution resembles the distribution of CRF receptors in PCs.

(C) Schematic plot of the two receptor's affinities (upper panel). Activation of the receptors changes the PCs probability to be in an "up" state. The relationship between the neuromodulator concentration and the probability of the cell to be in an "up" state is depicted in the lower panel. Left of the black dashed line the PC has a probability to be in a "down" state. If the neuromodulators levels are to the right of the black dashed line the PC will be in an "up" state. (D) One second puff of $1 \mu \mathrm{M}$ of CRF (red underline) shifts the Cell to an "up" state. In our toy model it means the concentration of CRF was to the right of the dashed black line. (E) Complex spike shifts the PC between the membrane voltage states (upper panel). In the presence of CRF (red underline) the complex spike was unable to shift the cell to a "down" state. The PC became less "sensitive" to input from the olivo- cerebellar loop, due to modulation by CRF.
MF systems. The first two properties allow the CRF system to be sensitive to tonic and phasic signals and the third provides the possibility of a different functional role to each pathway.

The diverse effects CRF have on PCs are well documented. One study showed that by itself CRF doesn't induce a change in the simple spike firing rate but attenuates the increase in the simple spike firing rate in response to excitatory neurotransmitters (Bishop, 1990). In our ongoing research we demonstrate that in an in vitro preparation, application of CRF tends to shift PCs into their firing mode (Libster et al., 2010) (Figure 4D). Other studies demonstrated an increase in the PCs firing rate in response to CRF (Bishop and King, 1992; Bishop, 2002). CFs 
Table 2 | Neuromodulators of Purkinje cells.

\begin{tabular}{lll}
\hline Neuromodulator & Source & Receptors \\
\hline 5-HT & MdR, PnR And Serotonergic & 5-HT1A (Expression decreases in \\
& neurons in precerebellar regions & adults), 5-HT2A, B, 5-HT5A, 5-HT7 \\
(Bishop and Ho, 1985). & (Pazos and Palacios, 1985; Pazos \\
& et al., 1985; Kinsey et al., 2001; \\
& Geurts et al., 2002).
\end{tabular}

\section{Known effects}

In vitro

Augmenting the HCN current (Li et al., 1993).

Altering the bi-stability of PCs (Williams et al., 2002).

Increases PC excitability by decreasing the IA current (Wang et al., 1992).

Decreases PC firing rate through activation of 5-HT1A, Applying 5-HT while blocking 5-HT1A causes an increase in firing rate (Darrow et al., 1990).

In vivo

Opposes changes in PC firing rate: increasing the rate when it becomes smaller and decreasing it when it becomes higher (Strahlendorf et al., 1984) effect can be species (Kerr and Bishop, 1992) and anesthesia (Strahlendorf et al., 1988) dependent. Reduces inward current caused by excitatory input (Hicks et al., 1989).

\begin{tabular}{|c|c|c|}
\hline NE & $\begin{array}{l}\text { LC (Watson and McElligott, } \\
\text { 1984; Loughlin et al., 1986a,b). }\end{array}$ & $\begin{array}{l}\text { Alpha adrenoreceptors 1A,B (low } \\
\text { levels), D(very low levels) (Day et al., } \\
\text { 1997), alpha adrenoreceptors2 } \\
\text { (Nicholas et al., 1993) and beta } \\
\text { adrenoreceptors2 (Wanaka et al., } \\
\text { 1989). }\end{array}$ \\
\hline
\end{tabular}

\section{In vitro}

Increases IPSCs amplitude. Mechanism is both post-synaptic (Woodward et al., 1991) and pre-synaptic (Saitow et al., 2000).

In vivo

Decreases the firing rate of PCs (Woodward et al., 1991).

\begin{tabular}{ll}
\hline Ach & Vestibular nuclei (non-beaded \\
& fibers) PTg, GiC and Raphe \\
& nuclei (beaded fibers) (Jaarsma \\
& et al., 1997).
\end{tabular}

Musacrenic receptors expression, mainly m2, is seen in the PCs layer in a species dependent fashion (Jaarsma et al., 1995) and Nicotinic receptors (Wada et al., 1989; Graham et al., 2002).

\section{In vivo}

Decreases the firing rate of PCs by activation of nicotinic receptors (De La Garza et al., 1987).

\begin{tabular}{|c|c|c|c|}
\hline Dopamine & VTA (Ikai et al., 1992). & $\begin{array}{l}\text { DAT presence is demonstrated } \\
\text { (Delis et al., 2004, 2008) and } \\
\text { D2,D3,D4,D5 receptors (Khan et al., } \\
\text { 1998, 2000; Kim et al., 2009). }\end{array}$ & $\begin{array}{l}\text { In vitro } \\
\text { Autocrine release from PCs. causes a slow } \\
\text { inward cation current. (Kim et al., 2009). }\end{array}$ \\
\hline Histamine & TMN (Haas and Panula, 2003). & $\begin{array}{l}\mathrm{H} 1, \mathrm{H} 2 \text {, and H3 (Drutel et al., 2001; } \\
\text { Takemura et al., 2003). }\end{array}$ & $\begin{array}{l}\text { In vitro } \\
\text { Causes release of calcium from intracellular } \\
\text { storages (Kirischuk et al., 1996). } \\
\text { Increases PC firing rate through activation of } \\
\text { H2 (Tian et al., 2000). }\end{array}$ \\
\hline
\end{tabular}

have a basal firing rate, so we can view the CFs as setting the tonic levels of CRF, and by activation the CRF-R1 (Figure 4B green), increasing the PCs excitability without increasing PCs firing rate. A phasic increase in CRF, either due to increase in the CF activity or released from MFs, will activate the low affinity CRF-R2 receptor which is located mainly on the PCs axon initial segment (Figure 4B orange) (Bishop et al., 2000). We propose, therefore, that cerebellar CRF system is organized in a way that low tonic level, CRF serves to modulate the sensitivity of PCs to excitatory input and in higher level it directly increase PC's firing rate (Figure 4E). Increasing the firing rate lowers the probability of PCs transitions to a down state and reduces the sensitivity to external inputs (Figure $4 \mathrm{E}$ ). This possible model mechanism is realized in Figure 4C. The sensitivity of the two receptors is depicted as dose response curves in Figure 4C and can be translated into the probability to shift to an up state (Figure 4C). In our hypothetical model the steeper probability curve of the low affinity receptor denotes a threshold 

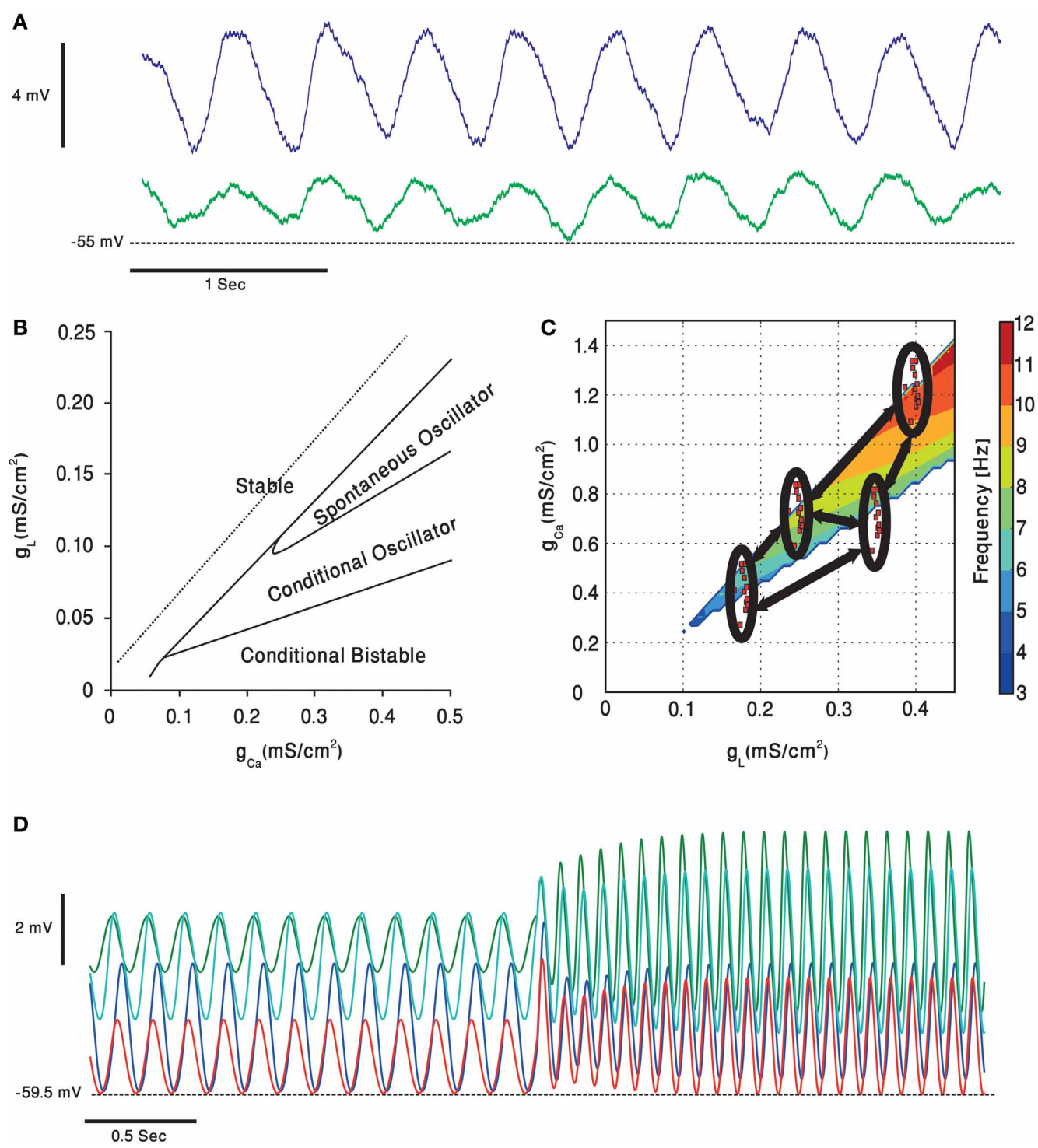

FIGURE 5 | Subthreshold oscillations of the olivary neurons

membrane potential. (A) Whole cell recording, in an in vitro preparation, of two coupled olivary neurons oscillating together. (B) A simulated olivary neuron behavior on dependence on the calcium and potassium leak conductance [adapted from Manor et al. (1997)]. Oscillations spontaneously occur in a restricted part of the plane. (C) Dependence of the olivary neurons subthreshold oscillations frequency, in the clustered olive model, on potassium leak and calcium conductance [adapted from Torben-Nielsen et al. (2012)]. Each of the clusters (red dots inside black ellipses) contains cells having, roughly, the same value of conductance. The cells inside the clusters have higher coupling coefficients relative to each other and lower coupling strength (marked in black arrows) to cells from other clusters. (D) The clustered olive model provides the olivary cells with phase invariance relative to the frequency. Each of the voltage traces is taken from a cell in a different cluster. The cells oscillate in a phase, relative to each other, which is preserved when the oscillation frequency is suddenly increased [adapted from Torben-Nielsen et al. (2012)]. like response to CRF level. Activating the high affinity receptors increases the probability to shift to firing mode (Figure 4D). Activating the low affinity receptors directly activates the PCs (orange line, Figure 4C). The entire range of electrical activity is grossly divided into two types of behavior (dashed vertical line). At low concentration of CRF, PC will shift to its firing mode upon synaptic input. At high concentration of CRF PCs shift to their firing mode, where the rate of firing increases with CRF levels. A transient increase in CRF level may, therefore, shift the PC to a continuous firing rendering it more input insensitive.

\section{THE OLIVARY NEURONS}

THE BIOPHYSICAL PROPERTIES OF OLIVARY NEURONS AND NETWORK

The role of the inferior olive, at least by some researchers, is to endow the cerebellar system with timing capabilities (Xu et al., 2006; Jacobson et al., 2008; Liu et al., 2008; Llinas, 2009). The electrophysiological manifestation of the timing capability 
Table 3 | Neuromodulators of the inferior olive.

\begin{tabular}{|c|c|c|c|}
\hline Neuromodulator & Source & Receptors & Known effects \\
\hline $5-\mathrm{HT}$ & $\begin{array}{l}\text { MAO receives from ROb and RPa } \\
\text { and DAO from GiC (Wiklund et al., } \\
\text { 1981a; Bishop and Ho, 1986). } \\
\text { Release sites can be either } \\
\text { junctional (close to the synapses) } \\
\text { or non junctional (Wiklund et al., } \\
\text { 1981b). }\end{array}$ & 5-HT2A, 5-HT5B (Kinsey et al., 2001). & $\begin{array}{l}\text { In vitro } \\
\text { Facilitates HCN current, reduces the inward } \\
\text { rectifying potassium current and LVA calcium } \\
\text { current (Placantonakis et al., 2000). } \\
\text { In vivo } \\
\text { Increases the average firing rate of inferior } \\
\text { olivary neurons and slowing their oscillation } \\
\text { frequency (Sugihara et al., 1995). }\end{array}$ \\
\hline NE & LC (Kobayashi et al., 1974). & $\begin{array}{l}\alpha \text {-adrenoreceptors1A,B (both with low } \\
\text { levels of expression) and D (high levels of } \\
\text { expression Day et al., 1997). } \\
\alpha \text {-adrenoreceptors2 (Probst et al., 1984) } \\
\text { and } \beta \text {-adrenoreceptors2 (Wanaka et al., } \\
\text { 1989). }\end{array}$ & \\
\hline Dopamine & $\begin{array}{l}\text { Prerubral parafascicular area } \\
\text { (mainly to the ventrolateral } \\
\text { outgrowth) (Toonen et al., 1998). }\end{array}$ & $\begin{array}{l}\text { D2 and D3 receptors (Bouthenet et al., } \\
\text { 1987, 1991). }\end{array}$ & \\
\hline
\end{tabular}

is the subthreshold membrane potential oscillations (Figure 5A), reflecting the network organization of the nucleus. It has been suggested that these oscillations emerge when a sufficient number of neurons are electrically coupled (Manor et al., 1997; Devor and Yarom, 2002; Torben-Nielsen et al., 2012) Indeed, electrical coupling between olivary neurons was demonstrated in physiological experiments and gap junction, the structural correlate of electrical connection, was identified in ultrastructure examinations (Llinas et al., 1974; Sotelo et al., 1974; Devor and Yarom, 2002; Leznik and Llinas, 2005). The gap junctions are located between dendritic spines and surrounded by inhibitory and excitatory synaptic terminals, forming a distinct structure known as the olivary glumerulus (King, 1976; De Zeeuw et al., 1998). This special arrangement indicates that the coupling strength is under synaptic regulation and therefore the formation of an oscillating network is controlled by synaptic inputs (Devor et al., 2001; Bazzigaluppi et al., 2012). The inhibitory input to the olivary glumerulus is provided by the inhibitory projection neurons of the deep CN (Bazzigaluppi et al., 2012) that are directly controlled by the PC's inhibitory input. The output of the olivary neurons ascends to the cerebellar cortex where it forms the CF synapse, thereby completing the olivo-cerebellar loop (Uusisaari and De Schutter, 2011).
Several models have been proposed to account for network dependent subthreshold voltage oscillations. The heterogeneity model assumes that olivary neurons are a heterogeneous population of neurons that differ in the density of their calcium and leak channels. This heterogeneity results in different types of neuronal behavior (see Figure 5B) that upon coupling generate subthreshold oscillations. In a recent study it was demonstrated that coupling strength can also shift the frequency of oscillations (Figure 5C), provided that the network is organized in clusters of coupled neurons (Torben-Nielsen et al., 2012). It follows that any global effect on calcium or leak channels, like that provided by neuromodulators, can alter the oscillation's frequency and thereby modulates the timing signal generated by the olivo-cerebellar loop.

\section{NEUROMODULATION OF OLIVARY NEURONS AND NETWORK}

Table 3 summarizes some of the current knowledge on the neuromodulators operating within the inferior olive nucleus. Our consideration on the functional effects of neuromodulators on olivary activity is based on two assumptions. First, the subthreshold oscillations are the source for cerebellar time coding and time representation. This timing capability serves both sensory and motor function. In sensory processing, time serves to 
predict motor outcomes, whereas in motor processing it provides temporal patterns to accurately execute motor commands. Second, we assume that the subthreshold oscillations are generated from complex interactions between intrinsic membrane properties and electrotonic connections that are best described by our heterogeneity model (see above).

With these assumptions one should wonder: should representation of time be modulated? Do we need a different representation of time in different behavioral sates? It is rather difficult, if not impossible, to answer these questions. It seems inevitable to conclude that time representation should be accurately preserved irrespective of the behavioral state. After all keeping accurate time is crucial for survival. Keeping accurate time for predicting motor outcome is definitely essential, but execution of motor commands is, and should be, modified upon a shift in the behavioral state. Motor performance is affected by the current level of alertness and motivation. Increase alertness is associated with faster movement time (Gray, 2011; Shiner et al., 2012). Therefore, an increase in movement velocity that maintains the temporal structure of the movement entails a change in the temporal pattern generated by the cerebellar system. We propose that these contradictory needs, preserving time representation for sensory function and altering timing of motor execution, are manifested in the non-homogeneous innervations of the olivary complex by neuromodulators. In the case of serotonergic innervations, some parts are heavily innervated while others are almost or completely devoid of such innervations (Wiklund et al., 1977; Leger et al., 2001). Thus, if behavioral state defines the serotonin level, the function will be modified in some olivary subnuclei while preserved in others.

\section{REFERENCES}

Abeles, M., Bergman, H., Gat, I., Meilijson, I., Seidemann, E., Tishby, N., et al. (1995). Cortical activity flips among quasi-stationary states. Proc. Natl. Acad. Sci. U.S.A. 92, 8616-8620.

Agnati, L. F., Leo, G., Zanardi, A., Genedani, S., Rivera, A., Fuxe, K., et al. (2006). Volume transmission and wiring transmission from cellular to molecular networks: history and perspectives. Acta Physiol. 187, 329-344.

Alviña, K., Ellis-Davies, G., and Khodakhah, K. (2009). T-type calcium channels mediate rebound firing in intact deep cerebellar neurons. Neuroscience 158, 635-641.

Alviña, K., Walter, J. T., Kohn, A., EllisDavies, G., and Khodakhah, K. (2008). Questioning the role of rebound firing in the cerebellum. Nat. Neurosci. 11, 1256-1258.

Association A. P. (2000). Diagnostic and Statistical Manual of Mental Disorders DSM-IV-TR, 4th Edn. Washington: Amer Psychiatric Pub.

To understand how temporal patterns can be modified in a way that will support faster movements one should consider the heterogeneity model. The gl-gCa plane shown in Figure 5C demonstrates that the higher the leak and the calcium conductance, the higher is the frequency of oscillation. Serotonin decreases both conductance and therefore a lower frequency is expected and indeed was experimentally observed (Sugihara et al., 1995; Placantonakis et al., 2000). We previously demonstrated that under harmaline intoxication sudden shifts in frequency of cortical complex spikes activity was frequently observed (Jacobson et al., 2009; Choi et al., 2010). Interestingly during this frequency shift, the phase difference between neurons was maintained. Similar phenomenon is also predicted by our heterogeneity model (Figure 5D). It is tempting to suggest that neuromodulators can change the frequency of the temporal pattern while maintaining the temporal order within the pattern, thus producing faster movement while maintaining coordination.

\section{CONCLUDING REMARKS}

This short review is focused on the effects of modulatory agents that operate within the olivo-cerebellar system. Beyond references to published studies, we presented various hypothetical possibilities by which neuromodulators can exert differential effects that are both spatial and temporal specific. We speculate that such mechanisms endowed the system with the capabilities to adjust cerebellar processing to a given behavioral state.

\section{ACKNOWLEDGMENTS}

Supported by PITN-GA-2009-238686 (CEREBNET), FP7-ICT (REALNET) and ISF (Yosef Yarom).

state and state-dependent cognitive processes. Brain Res. Brain Res. Rev. 42, 33-84.

Bishop, G. A. (1990). Neuromodulatory effects of corticotropin releasing factor on cerebellar Purkinje cells: an in vivo study in the cat. Neuroscience 39, 251-257.

Bishop, G. A. (2002). Development of a corticotropin-releasing factormediated effect on the firing rate of Purkinje cells in the postnatal mouse cerebellum. Exp. Neurol. 178, 165-174.

Bishop, G. A., and Ho, R. H. (1985). The distribution and origin of serotonin immunoreactivity in the rat cerebellum. Brain Res. 331, 195-207.

Bishop, G. A., and Ho, R. H. (1986) Cell bodies of origin of serotoninimmunoreactive afferents to the inferior olivary complex of the rat. Brain Res. 399, 369-373.

Bishop, G. A., and King, J. S. (1992). Differential modulation of Purkinje cell activity by enkephalin and corticotropin releasing factor. Neuropeptides 22, 167-174.
Bishop, G. A., Seelandt, C. M., and King, J. S. (2000). Cellular localization of corticotropin releasing factor receptors in the adult mouse cerebellum. Neuroscience 101, 1083-1092.

Boehme, R., Uebele, V. N., Renger, J. J., and Pedroarena, C. (2011) Rebound excitation triggered by synaptic inhibition in cerebellar nuclear neurons is suppressed by selective T-type calcium channel block. J. Neurophysiol. 106, 2653-2661.

Bouthenet, M. L., Martres, M. P., Sales, N., and Schwartz, J. C. (1987). A detailed mapping of dopamine D-2 receptors in rat central nervous system by autoradiography with [125I]iodosulpride. Neuroscience 20, 117-155.

Bouthenet, M. L., Souil, E., Martres, M. P., Sokoloff, P., Giros, B., and Schwartz, J. C. (1991). Localization of dopamine D3 receptor mRNA in the rat brain using in situ hybridization histochemistry: comparison with dopamine D2 receptor mRNA. Brain Res. 564, 203-219. 
Burgess, C. R. (2010). Histamine and orexin in the control of arousal, locomotion, and motivation. J. Neurosci. 30, 2810-2811.

Carter, M. E., Yizhar, O., Chikahisa, S., Nguyen, H., Adamantidis, A., Nishino, S., et al. (2010). Tuning arousal with optogenetic modulation of locus coeruleus neurons. Nat. Neurosci. 13, 1526-1533.

Chan-Palay, V. (1977). Cerebellar Dentate Nucleus: Organization, Cytology and Transmitters. Berlin; Heidelberg; New York: Springer-Verlag.

Chaudhury, D., Walsh, J. J., Friedman, A. K., Juarez, B., Ku, S. M., Koo, J. W., et al. (2013). Rapid regulation of depression-related behaviours by control of midbrain dopamine neurons. Nature 493, 532-536.

Choi, D. S., and Maroteaux, L. (1996). Immunohistochemical localisation of the serotonin 5-HT2B receptor in mouse gut, cardiovascular system, and brain. FEBS Lett. 391, 45-51.

Choi, S., Yu, E., Kim, D., Urbano, F. J., Makarenko, V., Shin, H.-S., et al. (2010). Subthreshold membrane potential oscillations in inferior olive neurons are dynamically regulated by $\mathrm{P} / \mathrm{Q}-$ and T-type calcium channels: a study in mutant mice. J. Physiol. 588, 3031-3043.

Cluderay, J. E., Harrison, D. C., and Hervieu, G. J. (2002). Protein distribution of the orexin-2 receptor in the rat central nervous system. Regul. Pept. 104, 131-144.

Cummings, S. L., Young, W. S. 3rd., Bishop, G. A., De Souza, E. B., and King, J. S. (1989). Distribution of corticotropin-releasing factor in the cerebellum and precerebellar nuclei of the opossum: a study utilizing immunohistochemistry, in situ hybridization histochemistry, and receptor autoradiography. J. Comp. Neurol. 280, 501-521.

Darrow, E. J., Strahlendorf, H. K., and Strahlendorf, J. C. (1990). Response of cerebellar Purkinje cells to serotonin and the 5-HT1A agonists 8-OH-DPAT and ipsapirone in vitro. Eur. J. Pharmacol. 175, 145-153.

Day, H. E., Campeau, S., Watson, S. J. Jr., and Akil, H. (1997). Distribution of alpha 1a-, alpha 1b- and alpha 1dadrenergic receptor mRNA in the rat brain and spinal cord. J. Chem. Neuroanat. 13, 115-139.

Dayan, P. (2012). Twenty-five lessons from computational neuromodulation. Neuron 76, 240-256.

De La Garza, R., McGuire, T. J., Freedman, R., and Hoffer, B. J.
(1987). The electrophysiological effects of nicotine in the rat cerebellum: evidence for direct postsynaptic actions. Neurosci. Lett. 80, 303-308.

De Zeeuw, C. I., Simpson, J. I. Hoogenraad, C. C., Galjart, N., Koekkoek, S. K., and Ruigrok, T. J. (1998). Microcircuitry and function of the inferior olive. Trends Neurosci. $21,391-400$.

Delis, F., Mitsacos, A., and Giompres, P. (2004). Dopamine receptor and transporter levels are altered in the brain of Purkinje Cell Degeneration mutant mice. Neuroscience 125 255-268.

Delis, F., Mitsacos, A., and Giompres, P. (2008). Pharmacological characterization and anatomical distribution of the dopamine transporter in the mouse cerebellum. Cerebellum 7, 242-251.

Devor, A., Fritschy, J. M., and Yarom, Y. (2001). Spatial distribution and subunit composition of GABA(A) receptors in the inferior olivary nucleus. J. Neurophysiol. 85, 1686-1696.

Devor, A., and Yarom, Y. (2002). Electrotonic coupling in the inferior olivary nucleus revealed by simultaneous double patch recordings. J. Neurophysiol. 87 3048-3058.

Di Mauro, M., Fretto, G., Caldera, M., Li Volsi, G., Licata, F., Ciranna, L., et al. (2003). Noradrenaline and 5-hydroxytryptamine in cerebellar nuclei of the rat: functional effects on neuronal firing. Neurosci. Lett. $347,101-105$

Di Mauro, M., Li Volsi, G., and Licata, F. (2012). Noradrenergic control of neuronal firing in cerebellar nuclei: modulation of GABA responses. Cerebellum. doi: 10.1007/s12311012-0422-2. [Epub ahead of print].

Dietrichs, E., and Haines, D. E. (1989). Interconnections between hypothalamus and cerebellum. Anat. Embryol. 179, 207-220.

Drutel, G., Peitsaro, N., Karlstedt, K., Wieland, K., Smit, M. J., Timmerman, H., et al. (2001) Identification of rat $\mathrm{H} 3$ receptor isoforms with different brain expression and signaling properties. Mol. Pharmacol. 59, 1-8.

Engbers, J. D., Anderson, D. Tadayonnejad, R., Mehaffey, W. H., Molineux, M. L., and Turner, R. W. (2011). Distinct roles for $\mathrm{I}(\mathrm{T})$ and $\mathrm{I}(\mathrm{H})$ in controlling the frequency and timing of rebound spike responses. J. Physiol. 589, 5391-5413.

Engbers, J. D., Fernandez, F. R., and Turner, R. W. (2012). Bistability in
Purkinje neurons: Ups and downs in cerebellar research. Neural Netw. doi: 10.1016/j.neunet.2012.09.006 [Epub ahead of print].

Errico, P., and Barmack, N. H. (1993). Origins of cerebellar mossy and climbing fibers immunoreactive for corticotropin-releasing factor in the rabbit. J. Comp. Neurol. 336, 307-320.

Everitt, B. J., and Robbins, T. W (1997). Central cholinergic systems and cognition. Annu. Rev. Psychol. $48,649-684$.

Fanselow, E. E., Sameshima, K. Baccala, L. A., and Nicolelis, M. A. L. (2001). Thalamic bursting in rats during different awake behavioral states. Proc. Natl. Acad. Sci. U.S.A. 98, 15330-15335.

Gardette, R., Krupa, M., and Crepel, F. (1987). Differential effects of serotonin on the spontaneous discharge and on the excitatory amino acidinduced responses of deep cerebellar nuclei neurons in rat cerebellar slices. Neuroscience 23, 491-500.

Gauck, V., Thomann, M., Jaeger, D. and Borst, A. (2001). Spatial distribution of low- and high-voltageactivated calcium currents in neurons of the deep cerebellar nuclei. J. Neurosci. 21, RC158.

Gervasoni, D., Lin, S.-C., Ribeiro, S., Soares, E. S., Pantoja, J., and Nicolelis, M.aL. (2004). Global forebrain dynamics predict rat behavioral states and their transitions. J. Neurosci. 24, 11137-11147.

Geurts, F. J., De Schutter, E., and Timmermans, J.-P. (2002). Localization of 5-HT2A, 5-HT3, 5-HT5A and 5-HT7 receptor-like immunoreactivity in the rat cerebellum. J. Chem. Neuroanat. 24 , 65-74.

Graeff, F. G., Guimarães, F. S., De Andrade, T. G. C. S., and Deakin, J. F. W. (1996). Role of 5-HT in stress, anxiety, and depression. Pharmacol. Biochem. Behav. 54, 129-141.

Graham, A., Court, J. A., MartinRuiz, C. M., Jaros, E., Perry, R., Volsen, S. G., et al. (2002) Immunohistochemical localisation of nicotinic acetylcholine receptor subunits in human cerebellum. Neuroscience 113, 493-507.

Gray, R. (2011). Links between attention, performance pressure, and movement in skilled motor action. Curr. Dir. Psychol. Sci. 20, 301-306.

Haas, H., and Panula, P. (2003). The role of histamine and the tuberomamillary nucleus in the nervous system. Nat. Rev. Neurosci. 4, 121-130.

Hervieu, G. J., Cluderay, J. E., Harrison, D. C., Roberts, J. C., and Leslie,
R. A. (2001). Gene expression and protein distribution of the orexin-1 receptor in the rat brain and spinal cord. Neuroscience 103, 777-797.

Hicks, T. P., Krupa, M., and Crepel, F. (1989). Selective effects of serotonin upon excitatory amino acid-induced depolarizations of Purkinje cells in cerebellar slices from young rats. Brain Res. 492, 371-376.

Hobson, J. A., McCarley, R. W., and Wyzinski, P. W. (1975). Sleep cycle oscillation: reciprocal discharge by two brainstem neuronal groups. Science 189, 55-58.

Hokfelt, T., and Fuxe, K. (1969). Cerebellar monoamine nerve terminals, a new type of afferent fibers to the cortex cerebelli. Exp. Brain Res. 9, 63-72.

Holdefer, R. N., Houk, J. C., and Miller, L. E. (2005). Movementrelated discharge in the cerebellar nuclei persists after local injections of $\mathrm{GABA}(\mathrm{A})$ antagonists. J. Neurophysiol. 93, 35-43.

Hollerman, J. R., and Schultz, W. (1998). Dopamine neurons report an error in the temporal prediction of reward during learning. Nat Neurosci. 1, 304-309.

Ikai, Y., Takada, M., and Mizuno, N. (1994). Single neurons in the ventral tegmental area that project to both the cerebral and cerebellar cortical areas by way of axon collaterals. Neuroscience 61, 925-934.

Ikai, Y., Takada, M., Shinonaga, Y., and Mizuno, N. (1992). Dopaminergic and non-dopaminergic neurons in the ventral tegmental area of the rat project, respectively, to the cerebellar cortex and deep cerebellar nuclei. Neuroscience 51 , 719-728.

Inagaki, N., Yamatodani, A., AndoYamamoto, M., Tohyama, M., Watanabe, T., and Wada, H. (1988). Organization of histaminergic fibers in the rat brain. J. Comp. Neurol. 273, 283-300.

Irwin, S. (1968). Comprehensive observational assessment: Ia. A systematic, quantitative procedure for assessing the behavioral and physiologic state of the mouse. Psychopharmacologia 13, 222-257.

Ito, M. (2009). Functional roles of neuropeptides in cerebellar circuits. Neuroscience 162, 666-672.

Jaarsma, D., Levey, A. I., Frostholm, A., Rotter, A., and Voogd, J. (1995). Light-microscopic distribution and parasagittal organisation of muscarinic receptors in rabbit cerebellar cortex. J. Chem. Neuroanat. 9, 241-259. 
Jaarsma, D., Ruigrok, T. J., Caffe, R., Cozzari, C., Levey, A. I., Mugnaini, E., et al. (1997). Cholinergic innervation and receptors in the cerebellum. Prog. Brain Res. 114, 67-96.

Jacobs, B. L., and Fornal, C. A. (1997). Serotonin and motor activity. Curr. Opin. Neurobiol. 7, 820-825.

Jacobs, B. L., Martin-Cora, F. J., and Fornal, C. A. (2002). Activity of medullary serotonergic neurons in freely moving animals. Brain Res. Brain Res. Rev. 40, 45-52.

Jacobson, G. A., Lev, I., Yarom, Y., and Cohen, D. (2009). Invariant phase structure of olivo-cerebellar oscillations and its putative role in temporal pattern generation. Proc. Natl. Acad. Sci. U.S.A. 106, 3579-3584.

Jacobson, G. A., Rokni, D., and Yarom, Y. (2008). A model of the olivocerebellar system as a temporal pattern generator. Trends Neurosci. 31, 617-625.

Jankovic, J., Vuong, K. D., and Thomas, M. (2006). Psychogenic tremor: long-term outcome. CNS Spectr. 11, 501-508.

Kano, M., Hashimoto, K., and Tabata, T. (2008). Type-1 metabotropic glutamate receptor in cerebellar Purkinje cells: a key molecule responsible for long-term depression, endocannabinoid signalling and synapse elimination. Philos. Trans. R. Soc. Lond. B Biol. Sci. 363, 2173-2186.

Kerr, C. W., and Bishop, G. A. (1992). The physiological effects of serotonin are mediated by the $5 \mathrm{HT} 1 \mathrm{~A}$ receptor in the cat's cerebellar cortex. Brain Res. 591, 253-260.

Khan, Z. U., Gutierrez, A., Martin, R., Penafiel, A., Rivera, A., and De La Calle, A. (1998). Differential regional and cellular distribution of dopamine D2-like receptors: an immunocytochemical study of subtype-specific antibodies in rat and human brain. J. Comp. Neurol. 402, 353-371.

Khan, Z. U., Gutierrez, A., Martin, R., Penafiel, A., Rivera, A., and De La Calle, A. (2000). Dopamine D5 receptors of rat and human brain. Neuroscience 100, 689-699.

Kia, H. K., Miquel, M. C., Brisorgueil, M. J., Daval, G., Riad, M., El Mestikawy, S., et al. (1996). Immunocytochemical localization of serotonin1A receptors in the rat central nervous system. J. Comp. Neurol. 365, 289-305.

Kim, Y. S., Shin, J. H., Hall, F. S., and Linden, D. J. (2009). Dopamine signaling is required for depolarization-induced slow current in cerebellar Purkinje cells. J. Neurosci. 29, 8530-8538.

Kimura, H., McGeer, P. L., Peng, J. H., and McGeer, E. G. (1981). The central cholinergic system studied by choline acetyltransferase immunohistochemistry in the cat. J. Comp. Neurol. 200, 151-201.

King, J. S. (1976). The synaptic cluster (glomerulus) in the inferior olivary nucleus. J. Comp. Neurol. 165, 387-400.

King, J. S., and Bishop, G. A. (2002) The distribution and cellular localization of CRF-R1 in the vermis of the postnatal mouse cerebellum. Exp. Neurol. 178, 175-185.

Kinsey, A. M., Wainwright, A., Heavens, R., Sirinathsinghji, D. J., and Oliver, K. R. (2001). Distribution of 5ht(5A), 5-ht(5B), 5-ht(6) and 5HT(7) receptor mRNAs in the rat brain. Brain Res. Mol. Brain Res. 88, 194-198.

Kirischuk, S., Matiash, V., Kulik, A., Voitenko, N., Kostyuk, P., and Verkhratsky, A. (1996). Activation of P2-purino-, alpha 1-adreno and H1-histamine receptors triggers cytoplasmic calcium signalling in cerebellar Purkinje neurons. Neuroscience 73, 643-647.

Kitzman, P. H., and Bishop, G. A (1997). The physiological effects of serotonin on spontaneous and amino acid-induced activation of cerebellar nuclear cells: an in vivo study in the cat. Prog. Brain Res. 114 209-223.

Kobayashi, R. M., Palkovits, M., Kopin, I. J., and Jacobowitz, D. M. (1974) Biochemical mapping of noradrenergic nerves arising from the rat locus coeruleus. Brain Res. 77, 269-279.

Lee, K. H., Bishop, G. A., Tian, J. B., and King, J. S. (2004). Evidence for an axonal localization of the type 2 corticotropin-releasing factor receptor during postnatal development of the mouse cerebellum. Exp. Neurol. 187, 11-22.

Lee, S. H., and Dan, Y. (2012). Neuromodulation of brain states. Neuron 76, 209-222.

Leger, L., Charnay, Y., Hof, P. R. Bouras, C., and Cespuglio, R. (2001). Anatomical distribution of serotonin-containing neurons and axons in the central nervous system of the cat. J. Comp. Neurol. 433, 157-182.

Leznik, E., and Llinas, R. (2005) Role of gap junctions in synchronized neuronal oscillations in the inferior olive. J. Neurophysiol. 94, 2447-2456.

Li, S. J., Wang, Y., Strahlendorf, H. K., and Strahlendorf, J. C. (1993).
Serotonin alters an inwardly rectifying current (Ih) in rat cerebellar Purkinje cells under voltage clamp. Brain Res. 617, 87-95.

Libster, A. M., Lefler, Y., YaronJakoubovitch, A., and Yarom, Y. (2010). Ataxia and the olivocerebellar module. Funct. Neurol. $25,129-133$.

Lindsley, D. B. (1952). Psychological phenomena and the electroencephalogram. Electroencephalogr. Clin. Neurophysiol. 4, 443-456.

Liu, T., Xu, D., Ashe, J., and Bushara, K. (2008). Specificity of inferior olive response to stimulus timing. J. Neurophysiol. 100, 1557-1561.

Llinas, R., Baker, R., and Sotelo, C. (1974). Electrotonic coupling between neurons in cat inferior olive. J. Neurophysiol. 37, 560-571.

Llinas, R., and Sugimori, M. (1980a). Electrophysiological properties of in vitro Purkinje cell dendrites in mammalian cerebellar slices. J. Physiol. 305, 197-213.

Llinas, R., and Sugimori, M. (1980b) Electrophysiological properties of in vitro Purkinje cell somata in mammalian cerebellar slices. J. Physiol. 305, 171-195.

Llinas, R. R. (2009). Inferior olive oscillation as the temporal basis for motricity and oscillatory reset as the basis for motor error correction. Neuroscience 162, 797-804.

Loewenstein, Y., Mahon, S. Chadderton, P., Kitamura, K. Sompolinsky, H., Yarom, Y., et al. (2005). Bistability of cerebellar Purkinje cells modulated by sensory stimulation. Nat. Neurosci. 8 202-211.

Loughlin, S. E., Foote, S. L., and Bloom, F. E. (1986a). Efferent projections of nucleus locus coeruleus: topographic organization of cells of origin demonstrated by three-dimensional reconstruction. Neuroscience 18, 291-306.

Loughlin, S. E., Foote, S. L., and Grzanna, R. (1986b). Efferent projections of nucleus locus coeruleus: morphologic subpopulations have different efferent targets. Neuroscience 18, 307-319.

Lovenberg, T. W., Liaw, C. W. Grigoriadis, D. E., Clevenger, W., Chalmers, D. T., De Souza, E. B., et al. (1995). Cloning and characterization of a functionally distinct corticotropin-releasing factor receptor subtype from rat brain. Proc. Natl. Acad. Sci. U.S.A. 92, 836-840.

Manor, Y., Rinzel, J., Segev, I., and Yarom, Y. (1997). Low-amplitude oscillations in the inferior olive: a model based on electrical coupling of neurons with heterogeneous channel densities. J. Neurophysiol. 77, 2736-2752.

McGregor, R., and Siegel, J. M. (2010). Illuminating the locus coeruleus: control of posture and arousal. Nat. Neurosci. 13, 1448-1449.

McKay, B. E., McRory, J. E., Molineux, M. L., Hamid, J., Snutch, T. P., Zamponi, G. W., et al. (2006). $\mathrm{Ca}(\mathrm{V}) 3 \mathrm{~T}$-type calcium channel isoforms differentially distribute to somatic and dendritic compartments in rat central neurons. Eur. J. Neurosci. 24, 2581-2594.

Mendlin, A., Martin, F. J., Rueter, L. E., and Jacobs, B. L. (1996). Neuronal release of serotonin in the cerebellum of behaving rats: an in vivo microdialysis study. J. Neurochem. 67, 617-622.

Molineux, M. L., McRory, J. E., McKay, B. E., Hamid, J., Mehaffey, W. H., Rehak, R., et al. (2006). Specific Ttype calcium channel isoforms are associated with distinct burst phenotypes in deep cerebellar nuclear neurons. Proc. Natl. Acad. Sci. U.S.A. 103, 5555-5560.

Molineux, M. L., Mehaffey, W. H., Tadayonnejad, R., Anderson, D., Tennent, A. F., and Turner, R. W. (2008). Ionic factors governing rebound burst phenotype in rat deep cerebellar neurons. J. Neurophysiol. 100, 2684-2701.

Narayanan, N. S., Land, B. B., Solder, J. E., Deisseroth, K., and Dileone, R. J. (2012). Prefrontal D1 dopamine signaling is required for temporal control. Proc. Natl. Acad. Sci. U.S.A 109, 20726-20731.

Nicholas, A. P., Pieribone, V., and Hokfelt, T. (1993). Distributions of mRNAs for alpha-2 adrenergic receptor subtypes in rat brain: an in situ hybridization study. J. Comp. Neurol. 328, 575-594.

Notomi, T., and Shigemoto, R. (2004). Immunohistochemical localization of Ih channel subunits, HCN1-4, in the rat brain. J. Comp. Neurol. 471 241-276.

Pazos, A., Cortes, R., and Palacios, J. M. (1985). Quantitative autoradiographic mapping of serotonin receptors in the rat brain. II. Serotonin-2 receptors. Brain Res $346,231-249$.

Pazos, A., and Palacios, J. M. (1985). Quantitative autoradiographic mapping of serotonin receptors in the rat brain. I. Serotonin-1 receptors. Brain Res. 346, 205-230.

Peyron, C., Tighe, D. K., Van Den Pol, A. N., De Lecea, L., Heller H. C., Sutcliffe, J. G., et al. (1998). Neurons containing hypocretin 
(orexin) project to multiple neuronal systems. J. Neurosci. 18, 9996-10015

Pierce, E. T., Hoddevik, G. H., and Walberg, F. (1977). The cerebellar projection from the raphe nuclei in the cat as studied with the method of retrograde transport of horseradish peroxidase. Anat. Embryol. 152, 73-87.

Pillot, C., Heron, A., Cochois, V., Tardivel-Lacombe, J., Ligneau, X., Schwartz, J. C., et al. (2002). A detailed mapping of the histamine $\mathrm{H}(3)$ receptor and its gene transcripts in rat brain. Neuroscience 114, 173-193.

Placantonakis, D. G., Schwarz, C., and Welsh, J. P. (2000). Serotonin suppresses subthreshold and suprathreshold oscillatory activity of rat inferior olivary neurones in vitro. J. Physiol. 524( $\mathrm{Pt} \mathrm{3})$, 833-851.

Probst, A., Cortes, R., and Palacios, J. M. (1984). Distribution of alpha 2adrenergic receptors in the human brainstem: an autoradiographic study using $[3 \mathrm{H}] \mathrm{p}$-aminoclonidine. Eur. J. Pharmacol. 106, 477-488.

Qin, Y. T., Ma, S. H., Zhuang, Q. X., Qiu, Y. H., Li, B., Peng, Y. P., et al. (2011). Histamine evokes excitatory response of neurons in the cerebellar dentate nucleus via H2 receptors. Neurosci. Lett. 502, 133-137.

Ranade, S. P., and Mainen, Z. F. (2009). Transient firing of dorsal raphe neurons encodes diverse and specific sensory, motor, and reward events. J. Neurophysiol. 102, 3026-3037.

Rogers, T. D., Dickson, P. E., Heck, D. H., Goldowitz, D., Mittleman, G., and Blaha, C. D. (2011). Connecting the dots of the cerebro-cerebellar role in cognitive function: neuronal pathways for cerebellar modulation of dopamine release in the prefrontal cortex. Synapse 65, 1204-1212.

Safo, P. K., Cravatt, B. F., and Regehr, W. G. (2006). Retrograde endocannabinoid signaling in the cerebellar cortex. Cerebellum 5, 134-145.

Saitow, F., Murano, M., and Suzuki, H. (2009). Modulatory effects of serotonin on GABAergic synaptic transmission and membrane properties in the deep cerebellar nuclei. J. Neurophysiol. 101, 1361-1374.

Saitow, F., Satake, S., Yamada, J., and Konishi, S. (2000). betaadrenergic receptor-mediated presynaptic facilitation of inhibitory GABAergic transmission at cerebellar interneuron-Purkinje cell synapses. J. Neurophysiol. 84, 2016-2025.
Santoro, B., Chen, S., Luthi, A., Pavlidis, P., Shumyatsky, G. P., Tibbs, G. R., et al. (2000). Molecular and functional heterogeneity of hyperpolarization-activated pacemaker channels in the mouse CNS. J. Neurosci. 20, 5264-5275.

Sari, Y., Miquel, M. C., Brisorgueil, M. J., Ruiz, G., Doucet, E., Hamon, M., et al. (1999). Cellular and subcellular localization of 5hydroxytryptamine1B receptors in the rat central nervous system: immunocytochemical, autoradiographic and lesion studies. Neuroscience 88, 899-915.

Saxon, D. W., and Beitz, A. J. (1996). An experimental model for the non-invasive trans-synaptic induction of nitric oxide synthase in Purkinje cells of the rat cerebellum. Neuroscience 72, 157-165.

Schonewille, M., Khosrovani, S., Winkelman, B. H., Hoebeek, F. E., De Jeu, M. T., Larsen, I. M., et al. (2006). Purkinje cells in awake behaving animals operate at the upstate membrane potential. Nat. Neurosci. 9, 459-461, author reply 461.

Schultz, W., Dayan, P., and Montague, P. R. (1997). A neural substrate of prediction and reward. Science 275, 1593-1599.

Schwartz, J. C., Arrang, J. M., Garbarg, M., Pollard, H., and Ruat, M. (1991). Histaminergic transmission in the mammalian brain. Physiol. Rev. 71, 1-51.

Schweighofer, N., Doya, K., and Kuroda, S. (2004). Cerebellar aminergic neuromodulation: towards a functional understanding. Brain Res. Brain Res. Rev. 44, 103-116.

Shen, B., Li, H.-Z., and Wang, J.-J. (2002). Excitatory effects of histamine on cerebellar interpositus nuclear cells of rats through $\mathrm{H} 2$ receptors in vitro. Brain Res. 948, 64-71.

Shibuki, K., and Okada, D. (1991). Endogenous nitric oxide release required for long-term synaptic depression in the cerebellum. Nature 349, 326-328.

Shin, S. L., Hoebeek, F. E., Schonewille, M., De Zeeuw, C. I., Aertsen, A., and De Schutter, E. (2007). Regular patterns in cerebellar Purkinje cell simple spike trains. PLoS ONE 2:e485. doi:10.1371/journal.pone.0000485

Shiner, T., Seymour, B., Symmonds, M. Dayan, P., Bhatia, K. P., and Dolan, R. J. (2012). The effect of motivation on movement: a study of bradykinesia in Parkinson's disease. PLoS ONE 7:e47138. doi: 10.1371/journal.pone. 0047138
Somana, R., and Walberg, F. (1978) The cerebellar projection from locus coeruleus as studied with retrograde transport of horseradish peroxidase in the cat. Anat. Embryol. 155, 87-94.

Somana, R., and Walberg, F. (1979). The cerebellar projection from locus coeruleus as studied with retrograde transport of horseradish peroxidase in the cat. Anat. Embryol. 155, 87-94.

Sotelo, C., Llinas, R., and Baker, R. (1974). Structural study of inferior olivary nucleus of the cat: morphological correlates of electrotonic coupling. J. Neurophysiol. 37, 541-559.

Steriade, M., Timofeev, I., and Grenier, F. (2001). Natural waking and sleep states: a view from inside neocortical neurons. J. Neurophysiol. 85, 1969-1985.

Strahlendorf, J. C., Lee, M., Netzeband, J. G., and Strahlendorf, H. K (1988). Pentobarbital augments serotonin-mediated inhibition of cerebellar Purkinje cells. Neuroscience 27, 107-115.

Strahlendorf, J. C., Lee, M., and Strahlendorf, H. K. (1984). Effects of serotonin on cerebellar Purkinje cells are dependent on the baseline firing rate. Exp. Brain Res. 56, 50-58.

Sugihara, I., Lang, E. J., and Llinas, R. (1995). Serotonin modulation of inferior olivary oscillations and synchronicity: a multiple-electrode study in the rat cerebellum. Eur. J. Neurosci. 7, 521-534.

Swanson, L. W., Simmons, D. M. Whiting, P. J., and Lindstrom, J. (1987). Immunohistochemical localization of neuronal nicotinic receptors in the rodent central nervous system. J. Neurosci. 7, 3334-3342.

Tadayonnejad, R., Anderson, D. Molineux, M. L., Mehaffey, W. H., Jayasuriya, K., and Turner, R. W. (2010). Rebound discharge in deep cerebellar nuclear neurons in vitro. Cerebellum 9, 352-374.

Taheri, S., Zeitzer, J. M., and Mignot, E. (2002). The role of hypocretins (orexins) in sleep regulation and narcolepsy. Annu. Rev. Neurosci. 25, 283-313.

Takemura, M., Kitanaka, N., and Kitanaka, J. (2003). Signal transduction by histamine in the cerebellum and its modulation by N-methyltransferase. Cerebellum 2 , 39-43.

Tang, B., Zhang, J., Yu, L., Li, H. Z., Zhu, J. N., and Wang, J. J. (2008). Excitation of histamine on neuronal activity of cerebellar fastigial nucleus in rat. Inflamm. Res. 57(Suppl. 1), S41-S42.

Tian, J. B., and Bishop, G. A. (2003). Frequency-dependent expression of corticotropin releasing factor in the rat's cerebellum. Neuroscience 121, 363-377.

Tian, L., Wen, Y. Q., Li, H. Z., Zuo, C. C., and Wang, J. J. (2000). Histamine excites rat cerebellar Purkinje cells via $\mathrm{H} 2$ receptors in vitro. Neurosci. Res. 36, 61-66.

Toonen, M., Van Dijken, H., Holstege, J. C., Ruigrok, T. J., Koekkoek, S. K., Hawkins, R. K., et al. (1998). Light microscopic and ultrastructural investigation of the dopaminergic innervation of the ventrolateral outgrowth of the rat inferior olive. Brain Res. 802, 267-273.

Torben-Nielsen, B., Segev, I., and Yarom, Y. (2012). The generation of phase differences and frequency changes in a network model of inferior olive subthreshold oscillations. PLoS Comput. Biol. 8:e1002580. doi: 10.1371/ journal.pcbi. 1002580

Trudeau, L.-É. (2004). Glutamate cotransmission as an emerging concept in monoamine neuron function. J. Psychiatry Neurosci. 29, 296-310.

Trulson, M. E., and Jacobs, B. L. (1979). Raphe unit activity in freely moving cats: correlation with level of behavioral arousal. Brain Res. 163, 135-150.

Urban, N. N., Henze, D. A., and Barrionuevo, G. (1998). Amplification of perforant-path EPSPs in CA3 pyramidal cells by LVA calcium and sodium channels. J. Neurophysiol. 80, 1558-1561.

Uusisaari, M., and De Schutter, E. (2011). The mysterious microcircuitry of the cerebellar nuclei. J. Physiol. 589, 3441-3457.

Uusisaari, M., and Knöpfel, T. (2011). Functional classification of neurons in the mouse lateral cerebellar nuclei. Cerebellum 10, 637-646.

Veasey, S. C., Fornal, C. A., Metzler, C. W., and Jacobs, B. L. (1995) Response of serotonergic caudal raphe neurons in relation to specific motor activities in freely moving cats. J. Neurosci. 15, 5346-5359.

Veasey, S. C., Fornal, C. A., Metzler, C. W., and Jacobs, B. L. (1997). Single-unit responses of serotonergic dorsal raphe neurons to specific motor challenges in freely moving cats. Neuroscience 79, 161-169.

Wada, E., Wada, K., Boulter, J., Deneris, E., Heinemann, S., Patrick, J., et al. (1989). Distribution of alpha 2, 
alpha 3 , alpha 4 , and beta 2 neuronal nicotinic receptor subunit mRNAs in the central nervous system: a hybridization histochemical study in the rat. J. Comp. Neurol. 284, 314-335.

Wahl-Schott, C., and Biel, M. (2009). HCN channels: structure, cellular regulation and physiological function. Cell. Mol. Life Sci. 66, 470-494.

Walters, A. S., and Hening, W. A. (1992). Noise-induced psychogenic tremor associated with posttraumatic stress disorder. Mov. Disord. 7, 333-338.

Wamsley, J. K., Lewis, M. S., Young, W. S. 3rd., and Kuhar, M. J. (1981). Autoradiographic localization of muscarinic cholinergic receptors in rat brainstem. J. Neurosci. 1, 176-191.

Wanaka, A., Kiyama, H., Murakami, T., Matsumoto, M., Kamada, T., Malbon, C. C., et al. (1989). Immunocytochemical localization of beta-adrenergic receptors in the rat brain. Brain Res. 485, 125-140.

Wang, Y., Strahlendorf, J. C., and Strahlendorf, H. K. (1992). Serotonin reduces a voltagedependent transient outward potassium current and enhances excitability of cerebellar Purkinje cells. Brain Res. 571, 345-349.
Watson, M., and McElligott, J. G. (1984). Cerebellar norepinephrine depletion and impaired acquisition of specific locomotor tasks in rats. Brain Res. 296, 129-138.

Wiklund, L., Bjorklund, A., and Sjolund, B. (1977). The indolaminergic innervation of the inferior olive. 1. Convergence with the direct spinal afferents in the areas projecting to the cerebellar anterior lobe. Brain Res. 131, $1-21$.

Wiklund, L., Descarries, L., and Mollgard, K. (1981a). Serotoninergic axon terminals in the rat dorsal accessory olive: normal ultrastructure and light microscopic demonstration of regeneration after 5, 6-dihydroxytryptamine lesioning. J. Neurocytol. 10, 1009-1027.

Wiklund, L., Sjolund, B., and Bjorklund, A. (1981b). Morphological and functional studies on the serotoninergic innervation of the inferior olive. J. Physiol. 77, 183-186.

Williams, S. R., Christensen, S. R., Stuart, G. J., and Hausser, M. (2002). Membrane potential bistability is controlled by the hyperpolarization-activated current $\mathrm{I}(\mathrm{H})$ in rat cerebellar Purkinje neurons in vitro. J. Physiol. 539, 469-483.
Wilson, G. W., and Garthwaite, J. (2010). Hyperpolarizationactivated ion channels as targets for nitric oxide signalling in deep cerebellar nuclei. Eur. J. Neurosci. 31, 1935-1945.

Womack, M. D., and Khodakhah, K. (2002). Characterization of large conductance $\mathrm{Ca} 2+$-activated $\mathrm{K}+$ channels in cerebellar Purkinje neurons. Eur. J. Neurosci. 16, 1214-1222.

Womack, M. D., and Khodakhah, K. (2004). Dendritic control of spontaneous bursting in cerebellar Purkinje cells. J. Neurosci. 24, 3511-3521.

Woodward, D. J., Moises, H. C., Waterhouse, B. D., Yeh, H. H., and Cheun, J. E. (1991). The cerebellar norepinephrine system: inhibition, modulation, and gating. Prog. Brain Res. 88, 331-341.

Wu, X., Ashe, J., and Bushara, K. O. (2011). Role of olivocerebellar system in timing without awareness. Proc. Natl. Acad. Sci. U.S.A. 108, 13818-13822.

$\mathrm{Xu}$, D., Liu, T., Ashe, J., and Bushara, K. O. (2006). Role of the olivocerebellar system in timing. J. Neurosci. 26, 5990-5995.

Yartsev, M. M., Givon-Mayo, R., Maller, M., and Donchin, O. (2009). Pausing purkinje cells in the cerebellum of the awake cat. Front. Syst. Neurosci. 3:2. doi: 10.3389/neuro.06.002.2009

Yu, L., Zhang, X.-Y., Zhang, J., Zhu, J.-N., and Wang, J.-J. (2010). Orexins excite neurons of the rat cerebellar nucleus interpositus via orexin 2 receptors in vitro. Cerebellum 9, 88-95.

Conflict of Interest Statement: The authors declare that the research was conducted in the absence of any commercial or financial relationships that could be construed as a potential conflict of interest.

Received: 10 January 2013; accepted: 03 April 2013; published online: 19 April 2013.

Citation: Libster AM and Yarom $Y$ (2013) In and out of the loop: external and internal modulation of the olivocerebellar loop. Front. Neural Circuits 7:73. doi: 10.3389/fncir.2013.00073 Copyright (c) 2013 Libster and Yarom. This is an open-access article distributed under the terms of the Creative Commons Attribution License, which permits use, distribution and reproduction in other forums, provided the original authors and source are credited and subject to any copyright notices concerning any third-party graphics etc. 